\title{
A PEDAGOGIA DIALÓGICO-POLIFÔNICA DE PAULO FREIRE: UM ANTÍDOTO CONTRA O EMERGENTE PENSAMENTO AUTORITÁRIO E ANTI DEMOCRÁTICO
}

\author{
Reuber Gerbassi Scofano ${ }^{1}$
}

\begin{abstract}
RESUMO
O trabalho faz uma leitura da obra de Paulo Freire a partir de ponto de vista pós colonial, ou decolonial. Examina sua originalidade ainda que não desconheça a influência recebida pelo pensamento de Hegel, Karl Marx, Karl Jaspers, Martin Buber, Gabriel Marcel e Jean Paul Sartre. Acentua a criação do termo Dodiscência que elimina a relação de supremacia do docente sobre o discente abrindo com esse conceito as portas para uma relação dialogal, respeitosa e de aprendizado mútuo entre professor e aluno. Dodiscência é conceito fundamental para se entender a reviravolta que provocou no campo educacional e sua centralidade da luta contra o pensamento autoritário. Nesse sentido, sua concepção do espaço escolar como círculo de cultura, no qual o papel do professor é o de coordenar os debates e do aluno é de ser participante do círculo de cultura, invertem a lógica do autoritarismo pedagógico.
\end{abstract}

Palavras-chave: Pedagogia dialógica. Dodiscência. Problematizar o Pensamento Pedagógico.

PAULO FREIRE'S DIALOGICAL-POLYPHONIC PEDAGOGY: AN ANTIDOTE AGAINST THE EMERGING AUTHORITARIAN AND ANTI-DEMOCRATIC THOUGHT

\begin{abstract}
This text makes a reading of Paulo Freire's work from a post-colonial, or decolonial point of view, that is, it examines its originality even though it is not unaware of the influence received by the thought of Hegel, Karl Marx, Karl Jaspers, Martin Buber, Gabriel Marcel and Jean Paul Sartre. The creation of the term Dodiscencia is emphasized here, which eliminates the relationship of supremacy of the teacher over the student, opening with this concept the doors to a dialogical, respectful and mutual learning relationship between teacher and student. Dodiscencia is a fundamental concept for us to understand the upheaval it has caused in the educational field and its centrality in the fight against authoritarian thinking. In this sense, his conception of the school as crop circle in which the teacher's role is to coordinate the discussions and the student is to be a participant of the crop circle, reverse the logic of pedagogical authoritarianism.
\end{abstract}

Keywords: Dialogical pedagogy. Dodiscência. Problematizing pedagogy.

LA PEDAGOGÍA DIALÓGICO-POLIFÓNICA DE PAULO FREIRE: UN ANTÍDOTO CONTRA EL PENSAMIENTO AUTORITARIO Y ANTIDEMOCRÁTICO EMERGENTE

\section{RESUMEN}

Es una reinterpretación de la obra de Paulo Freire desde un punto de vista poscolonial o decolonial, es decir, examina su originalidad aunque no ignora la influencia que recibió el pensamiento de Hegel, Karl Marx, Karl Jaspers, Martin Buber., Gabriel Marcel y Jean Paul Sartre. Aquí se enfatiza la creación del término Dodiscencia, que elimina la relación de supremacía del docente sobre el alumno, abriendo con

\footnotetext{
${ }^{1}$ Pós-Doutorado em Educação pela Universidade Federal Fluminense, Doutor e Mestre em Educação pela UFRJ, Bacharel e Licenciado em Filosofia pela UFRJ. Professor da Universidade Federal do Rio de Janeiro.
} 
este concepto las puertas a una relación de aprendizaje dialógica, respetuosa y mutua entre docente y alumno. La dodiscencia es un concepto fundamental para que entendamos el revuelo que provocó en el ámbito educativo y su centralidad en la lucha contra el pensamiento autoritario. En este sentido, su concepción del espacio escolar como un círculo de cultura, en el que el rol del docente es coordinar los debates y el alumno es ser partícipe del círculo cultural, invirtiendo la lógica del autoritarismo pedagógico.

Palabras clave: Pedagogía dialógica. Dodiscencia. Problematizar el pensamiento pedagógico.

Paulo Freire é sem a menor sombra de dúvida o maior educador brasileiro e tem sua obra reconhecida no mundo inteiro. Sua obra é estudada nos quatro cantos do planeta e poderíamos dizer que se tornou uma referência para todos aqueles que lutam por uma educação de qualidade apoiada na promoção humana a partir do diálogo e respeito às culturas locais.

O pensamento freiriano é hoje referência também nos estudos e pesquisas do campo Decolonial.

O presente trabalho visa uma apresentação de algumas das principais contribuições da pedagogia de Paulo Freire que valorizam uma prática educacional visando o encontro, o diálogo e a partilha de experiências culturais entre educador e educando.

A obra de Paulo Freire é um verdadeiro libelo contra as práticas educacionais autoritárias tradicionais. Isso faz dele um autor ainda mais atual em um momento que o mundo vem apresentando a ascensão de teorias fascistas, supremacistas e muitas vezes até negacionistas de conhecimentos que já fazem parte do patrimônio científico da humanidade.

Pensador da mais alta categoria, conhecedor de pilares do pensamento ocidental da grandeza de Hegel, Karl Marx, Karl Jaspers, Martin Buber, Gabriel Marcel e Jean Paul Sartre, criou conceitos no campo educacional que expressam a ressignificação que empreendeu a partir de tais filósofos.

Criou um pensamento original elaborando uma resdescrição do processo educativo tanto no campo que se refere à discussão do que é educar bem como qual o papel do educador, do educando e da comunidade onde se realiza o ato educativo.

Paulo Freire revolucionou a relação Educador-Educando desmontando o autoritarismo na relação e este é um dos motivos de ser tão odiado pelos setores conservadores da sociedade.

Seus textos Pedagogia do Oprimido, Pedagogia da Autonomia, Pedagogia da Esperança e Educação como Prática de Liberdade servirão de base para nosso trabalho.

Considero tais obras a base fundamental do pensamento educacional freiriano, pois nelas a perspectiva dialogal da educação fica explícita. 
Paulo Freire inclusive criou o termo Dodiscência que elimina a relação de supremacia do docente sobre o discente abrindo com esse conceito as portas para uma relação dialogal, respeitosa e de aprendizado mútuo entre professor e aluno. Dodiscência é um conceito fundamental para entendermos a reviravolta que ele provocou no campo educacional.

Em sua obra Educação como Prática de Liberdade podemos contemplar o DNA da pedagogia freiriana, pois nessa obra aparecem as sementes de tudo que se desenvolverá posteriormente. O mais interessante é que nessa obra da década de 1960 já podemos contemplar uma defesa intransigente do respeito à cultura local dos educandos e toda a bagagem que trazem de sua comunidade. Esse aspecto é central em Paulo Freire e acredito que seja algo que todo e qualquer educador deveria observar.

Vale à pena registrar que a influência benfazeja de Paulo Freire não se restringiu ao processo de alfabetização. Podemos contemplar hoje em dia a presença de Paulo Freire no ensino de Língua Portuguesa, Matemática, Geografia, História, Língua estrangeira, Filosofia, Sociologia, Física, Química, Psicologia, Enfermagem, Nutrição, Teatro, Artes Plásticas, etc.

Vejamos como é atual: "Sempre confiáramos no povo. Sempre rejeitáramos fórmulas doadas. Sempre acreditáramos que tínhamos algo a permutar com ele, nunca exclusivamente a oferecer-lhe." (Freire, 1977, p.102)

A proposta do ato educativo como troca de experiências e saberes é uma das contribuições mais importantes deixadas por Paulo Freire. O professor não é visto mais como o detentor absoluto do saber, é alguém que sabe ouvir as narrativas produzidas pela comunidade de onde o aluno vem. De certa forma, o professor também está aberto a em alguns momentos ser educando de seu educando.

Ambos ensinam e ambos aprendem sem que o professor perca sua autoridade, pois se trata de uma autoridade conquistada pela liderança respeitosa e amorosa para com os alunos e não a autoritarismo.

Em minha longa jornada como professor de inspiração freireana cheguei a ouvir de colegas que não concordavam com essa postura pedagógica e que Paulo Freire era um demagogo, pois para eles o professor não tem nada a aprender com o aluno, pois ele é alguém que estudou e se formou e o aluno nada é ainda. Pensamentos como este só demonstram a que ponto chega o preconceito e o despreparo de muitos professores. O interessante é que isto ocorre também no nível superior. Trata-se de uma visão centrada na figura do professor absolutista. Não é incomum que muitos desses professores acabem falhando em seu ensino, pois desestimulam os alunos tanto pelo conteúdo quanto pela forma. Apelam então para o terrorismo educacional utilizando dos testes e provas para ameaçar os alunos com o fantasma da nota baixa 
e a reprovação. Tentam assim manter o controle de sala de aula pela ameaça e repressão. Isso faz com que suas aulas percam o sabor do saber através de aulas vivas e instigantes para tornarem-se momentos de tédio e sofrimento.

E o pior que muitos desses professores autoritários sentem prazer com isso tudo, fazendo então do ato educativo um momento de exercer seu sadismo.

Paulo Freire nos ensinou que o educador deve conhecer os valores, os conhecimentos bem como os costumes dos educandos e inclusive avaliarem o que significa aquele momento para eles e o que lhes está proporcionando.

A educação é um processo de crescimento e de construção:

Experimentáramos métodos, técnicas, processos de comunicação. Superamos procedimentos. Nunca, porém, abandonamos a convicção que sempre tivemos, de que só nas bases populares e com elas, poderíamos realizar algo de sério e autêntico para com elas. Daí jamais admitirmos que a democratização da cultura, fosse a sua vulgarização ou, por outro lado, a doação ao povo, do que formulássemos nós mesmos em nossa biblioteca e que a ele entregássemos como prescrições a serem sugeridas. (FREIRE, 1977, p.102)

Paulo Freire também coloca sob seu crivo as concepções corriqueiras de escola, professor e aluno.

Ao refletir sobre o conceito de escola percebeu que se tratava de um conceito bastante desgastado, ligado a uma idéia de passividade e propôs o nome de Círculo de Cultura para os novos espaços educacionais que defendeu.

A palavra professor também era um termo bastante marcado por uma visão doadora e propôs ao educador o papel de coordenador de debates.

Ao invés de aluno, termo excessivamente passivo e sem luminosidade, propôs o termo participante do Círculo de Cultura no sentido de ser um aprendiz ativo.

A aula discursiva centrada na figura centralizadora do professor foi substituída pelo diálogo franco e respeitoso.

Freire propôs também que os programas fossem revistos afim de que saíssem daqueles modelos de pontos e unidades completamente desvinculados da vida real. A escola tradicional ensinava na maior parte do tempo conteúdos que não eram úteis nem tampouco prazerosos para os alunos.

Incontável número de educadores caminhou e caminha por esta perspectiva pedagógica libertadora e que visa a autonomia do educando.

Um dos exemplos que poderíamos citar é o caso da Escola da Ponte em Portugal que teve toda sua concepção e desenho pedagógico ancorada na proposta do educador freireano chamado José Pacheco. 
O filósofo e educador brasileiro Rubem Alves, também discípulo de Paulo Freire, em seu livro A Escola com que sempre sonhei sem imaginar que pudesse existir, nos conta a surpresa que teve ao deparar com essa escola em Portugal sendo apresentada por uma aluna:

Eu nunca tinha tido experiência semelhante e nunca imaginei que fosse possível que um diretor entregasse a uma aluna, menina de nove anos, a tarefa de mostrar e explicar a sua escola, a um educador estrangeiro.

A menina não se fez de rogada. Encaminhou-se resolutamente na direção da porta da escola, e eu obediente, a seguir. Chegando à porta, ela parou, voltouse para mim e disse em voz resoluta e confiante:

"para entender nossa escola, o senhor terá que esquecer tudo o que sabe sobre escolas. Não temos turmas, não temos alunos separados por classes, nossos professores não dão aulas com giz e lousa, não temos campainha separando o tempo, não temos provas e notas." (ALVES, 2001, p. 41)

Experiências como a da Escola da Ponte demonstram a atualidade das propostas educacionais de Paulo Freire, sendo que no caso dessa escola percebemos que ela avança um pouco mais. A concepção freireana de educação baseava-se em um pressuposto que negava o excessivo formalismo e autoritarismo da pedagogia tradicional que ele denominou Pedagogia Bancária. Essa informalidade libera o espaço escolar para novas experiências. Não é por acaso que Freire escolheu o título Pedagogia da Autonomia para sua última obra publicada em vida.

A Escola da Ponte apoiada na pedagogia freiriana implodiu o espaço escolar tradicional que adotara até então. Conservou o nome de escola, mas poderia muito bem ser nomeado Círculo Popular de Cultura.

Paulo Freire na obra Educação como prática de liberdade relata que a seqüência e organização dos debates tinham a participação ativa dos alunos, algo ainda muito incomum em nossos espaços educacionais.

A Pedagogia Bancária é extremamente centralizadora e encara o aluno como um indivíduo passivo e mero receptor. Essa concepção educacional infelizmente permanece em muitas de nossas instituições de ensino inclusive as Universidades.

Paulo Freire iniciou a crítica a esta prática pedagógica autoritária a partir dos métodos de alfabetização com os quais tomou conhecimento no início de seu trabalho como educador.

Observou então que o aluno era visto como um mero repositório de informações e submetido a um ensino infantilizado.

Na verdade, somente com muita paciência é possível tolerar após as durezas de um dia de trabalho ou de um dia "sem trabalho", lições que falam de ASA - "Pedro viu a asa" - "A asa é da ave.". Lições que falam de Evas e de uvas a homens que às vezes conhecem poucas Evas e nunca comeram uvas. "Eva viu a uva". Pensávamos numa alfabetização que fosse em si um ato de criação, capaz de desencadear outros atos criadores. Numa alfabetização em que o homem, porque não fosse seu paciente, seu objeto, desenvolvesse a 
impaciência, a vivacidade, característica dos estados de procura, de invenção e reivindicação. (FREIRE, 1977, p.104)

A perspectiva educacional freireana parte do princípio de que homem não é um ser que está no mundo, mas se trata de alguém que está com o mundo e isso é a base não só para os processos de alfabetização, mas para todo e qualquer momento educativo. Isso faz com que o ensino seja engajado tanto na vida comunitária e cultural como também na relação respeitosa e amorosa para com a natureza.

A pedagogia de Paulo Freire valoriza tremendamente as culturas locais, pois com elas aprende. Por exemplo, a prática do desenvolvimento sustentável na qual o homem abandona o papel de predador e passa a agir em parceria com a natureza é inspirada pelo aprendizado com as culturas tribais, mas também com os caboclos. O grande líder seringueiro Chico Mendes é um exemplo de alguém que ensinou a todos como retirar da natureza seu sustento sem provocar qualquer destruição.

O diálogo como pilar principal da pedagogia de Paulo Freire aparece de forma contundente especialmente quando ele propõe o conceito de dodiscência. Com este conceito defende a idéia de que a prática educativa acontece em sua plenitude quando ocorre troca entre educador e educando.

E o que é o diálogo? É uma relação horizontal de A com B. Nasce de uma matriz crítica e gera criticidade. Nutre-se do amor, da humildade, da esperança, da fé, da confiança. Por isso, só o diálogo comunica. E quando os dois pólos do diálogo se ligam assim, com amor, com esperança, com fé, um no outro, se fazem críticos na busca de algo. Instala-se, então, uma relação de simpatia entre ambos. (FREIRE, 1977, p.107)

Uma das fontes mais importantes de Paulo Freire foi o filósofo existencialista Karl Jaspers. Este filósofo alemão do século XX defendia o diálogo em toda e qualquer situação. É fundamental crermos no outro e também em sua potencialidade. O diálogo em Jaspers é um antídoto contra o antidiálogo tão presente em nossas vidas.

O antidiálogo propõe uma relação vertical entre A e B. Trata-se de relação desamorosa, arrogante, desesperançada e extremamente autoritária. Não há qualquer simpatia entre os dois participantes do diálogo, pois ali não se comunica, fazem-se comunicados.

Essa perspectiva anti dialógica, na visão de Freire, é recorrente na educação brasileira ainda hoje em todas as instituições educacionais contribuindo assim para a propagação da cultura autoritária. O número de professores despreparados para o diálogo ainda é assustador e isso é formador de educandos e futuros cidadãos acostumados ao autoritarismo.

Outro ponto que tem destaque central na pedagogia freiriana é a valorização da produção da cultura popular que passa a ter o mesmo status que a cultura erudita. 
O papel do educador antiautoritário é desde os primeiros contatos com os educandos deixar claro que não é o caso de trocar a cultura que você traz de sua comunidade por outra considerada mais correta. Trata-se de mostrar que ambas são importantes e todos saem ganhando quando há uma troca entre ambas, pois o repertório cultural de educadores e educandos se qualificam.

[...] tanto é cultura o boneco de barro feito pelos artistas, seus irmãos do povo, como é cultura também é a obra de um grande escultor, de um grande pintor, de um grande místico, ou de um grande pensador. Que cultura é a poesia dos poetas letrados de seu País, como também a poesia de seu cancioneiro popular. Que cultura é toda criação humana. (FREIRE, 1977, p.109)

Essa iniciativa cria um ambiente educacional de respeito ao outro, ao diferente e valoriza a polifonia de vozes, pois todos têm direito a sua bagagem cultural de origem e percebe-se o quanto o aluno cresce em autoestima quando se sente valorizado e protagonista no processo. A cultura tradicional da pedagogia Bancária recebia o aluno tratando-o como alguém vazio de cultura e o que trazia de sua comunidade era desprezado e muitas vezes submetido ao escárnio de professores sádicos que os tratavam como seres inferiores.

Em sua obra Pedagogia da Esperança Paulo Freire faz um relato que ilustra de forma cabal o que foi dito até aqui quando responde a um aluno que se dizia ignorante.

"Muito bem", disse em resposta à intervenção do camponês. "Aceito que eu sei que vocês não sabem. De qualquer forma, gostaria de lhes propor um jogo que, para funcionar bem, exige de nós absoluta lealdade. Vou dividir o quadro em dois pedaços, em que irei registrando, do meu lado e do lado de vocês, os gols que faremos eu, em vocês, vocês, em mim. O jogo consiste em cada um perguntar algo ao outro. Se o perguntado não sabe responder, é gol do perguntador. Começarei o jogo fazendo uma primeira pergunta a vocês".

A essa altura, precisamente porque assumira o "momento" do grupo, o clima era mais vivo do que quando começáramos, antes do silêncio. Primeira pergunta:

- Que significa a maiêutica socrática?

Gargalhada geral, e eu registrei o meu primeiro gol.

- Agora cabe a vocês fazer a pergunta a mim - disse.

-Que é curva de nível?

Não soube responder. Registrei um a um.

-Qual a importância de Hegel no pensamento de Marx?

Dois a um.

-Para que serve a calagem do solo?

Dois a dois.

-Que é um verbo intransitivo?

Três a dois.

-Qual a relação entre curva de nível e erosão?

Três a três.

-Que significa epistemologia?

Quatro a três.

O que é adubação verde?

Quatro a quatro.

Assim, sucessivamente até chegarmos a dez a dez. 
Ao me despedir deles, lhes fiz uma sugestão: "Pensem no que houve nesta tarde aqui. Vocês começaram discutindo muito bem comigo.

Em certo momento ficaram silenciosos e disseram que só eu poderia falar porque só eu sabia e vocês não. Fizemos um jogo sobre saberes e empatamos de dez a dez. Eu sabia dez coisas que vocês não sabiam e vocês sabiam dez coisas que eu não sabia. Pensem sobre isto. (FREIRE, 1992, p.48)

Como podemos ver nesse texto emblemático de Freire a valorização do saber e cultura local do aluno são extremamente valorizadas em um encontro que partilha saberes entre o educador e o educando.

Outra contribuição importantíssima que nosso educador maior nos legou e que permanece atual foi a concepção de que o ato de alfabetizar não consiste em ato meramente mecânico. Na verdade ele é um ato que proporciona ao alfabetizando a possibilidade de tomar posse da palavra como também do texto e, por conseguinte, da idéia que lhe está sendo transmitida afim de que possa concordar ou não com o enunciado transmitido.

Um ato crítico ao se defrontar com o texto e não uma mera repetição e memorização de palavras e letras sem sentido.

A partir de Paulo Freire, o ato de alfabetizar ultrapassou em muito o mero ato mecânico de se ler e escrever. Tornou-se algo consciente, pois se entende o que se apresenta para ser lido e a partir desse empoderamento da palavra, fala-se e escreve-se de forma autônoma e não autômata. Com isso, o aluno assume uma leitura crítica do texto, mas também de sua própria vida.

Implica não uma memorização visual e mecânica de sentenças, de palavras, de sílabas desgarradas de um universo existencial - coisas mortas ou semimortas, mas nunca numa atitude de criação e recriação. Implica uma autoformação de que possa resultar uma postura interferente do homem sobre seus contextos (FREIRE, 1977, p.111)

O educador assume um novo papel na perspectiva freireana de alfabetização centrada basicamente no diálogo com o alfabetizando.

A alfabetização se faz com os fatos concretos da vida e todas as suas circunstâncias culturais. Tijolo, areia, terra, semente passam a substituir palavras como Eva, Ivo, uva e vovó que eram usadas nas cartilhas de todo o país, do Oiapoque ao Chuí, sem levar em consideração as características culturais e costumes de cada região.

Paulo Freire rompeu definitivamente com a idéia de uma alfabetização autoritária feita de cima para baixo. Não se tratava mais de uma ação doadora por parte do professor, mas uma ajuda para que o aluno opere seu processo de alfabetização de dentro para fora.

Essa revolução freireana no campo da alfabetização provocou mudança em todos os segmentos educacionais e provocou debates riquíssimos no campo da didática. 
As cartilhas foram alvo de severas críticas de Freire, pois apresentavam um material oferecido para todo o país em uma perspectiva vertical e doadora colocando o alfabetizando em um lugar de objeto e não sujeito ativo e altivo de sua alfabetização. Alfabetização tem que ser um processo criativo como todo o ato educativo libertador ou não passa de mero adestramento.

O fundamental na alfabetização em uma língua silábica como a nossa é levar o homem a aprender criticamente o seu mecanismo de formação vocabular, para que faça, ele mesmo, o jogo criador das combinações. Não que sejamos contra os textos de leitura, que são outra coisa, indispensáveis ao desenvolvimento do canal visual gráfico, e que devem ser em grande parte elaborados pelos próprios "participantes". Acrescentemos que a nossa experiência se fundamenta no aprendizado da informação através de canais múltiplos de comunicação. (FREIRE, 1977, p.111)

Como conseqüência dessa grande contribuição freiriana, um número enorme de professores e mesmo aqueles que não trabalhavam diretamente com alfabetização passaram a questionar o ensino colonizado e passivo de nossas escolas em todas as séries e segmentos chegando essas discussões às universidades também.

O chamado Método Paulo Freire que tinha etapas como: Investigação do universo cultural, elaboração de material didático bem como a conscientização não somente revolucionou os processos de alfabetização em nosso país, mas também provocou professores das diversas áreas para repensarem seu trabalho como educador.

Professores das mais variadas áreas, passaram a utilizar em seus conteúdos exemplos trazidos pelos alunos e que ilustrassem como aquilo tudo que fora trabalhado em sala dialogava com a vida de cada aluno.

Em seu grande clássico Pedagogia do Ooprimido, Paulo Freire questionou o tratamento proporcionado por nossas escolas tradicionais ao apresentarem a realidade como um sistema estático, hierarquizado e compartimentado. Esta concepção da vida e do mundo é algo completamente estranho à vida real doas educandos. A pedagogia freireana diferentemente da Concepção Bancária da educação, aponta para uma nova perspectiva em que a vida real e a própria relação educador e educando passam a ser vistas em base que valoriza a mobilidade, o diálogo, a anti-hierarquia autoritária, a abertura às mudanças e ao novo e o respeito à experiência comunitária.

Quando criou o conceito de Educação Bancária, Paulo Freire através de uma metáfora brilhante captou a essência de uma prática hegemônica na cultura brasileira de então que se apoiava na Transmissão de conteúdos, no formalismo e no autoritarismo.

Nela, o educador aparece como seu indiscutível agente, como o seu real sujeito, cuja tarefa indeclinável é "encher" os educandos dos conteúdos de sua narração, conteúdos que são retalhos da realidade, desconectados da totalidade em que se engendram e em cuja visão ganharia significação. A palavra, nestas 
dissertações, se esvazia da dimensão concreta que devia ter ou se transforma em palavra oca e alienada e alienante. Daí que seja mais do que significação e, assim, melhor será não dizê-la.

Por isto mesmo, é que uma das características desta educação dissertadora é a "sonoridade" de palavras e não sua força transformadora. Quatro vezes quatro dezesseis. Pará capital Belém, que o educando fixa, memoriza, repete, sem perceber o que realmente é quatro vezes quatro. O que significa capital na afirmação Pará capital Belém, Belém para o Pará e Pará para o Brasil. (FREIRE, 1981, p. 65)

Uma pedagogia que oferece aos alunos somente a mecanização e memorização de conteúdos formais por meio do comunicado e do repasse.

Paulo Freire usa uma metáfora brilhante para expressá-la, trata-se do educando "vasilha".

A cabeça do aluno é visto como algo oco e será preenchido com informações tal como se o professor estivesse enchendo uma vasilha.

Neste modelo quanto mais o aluno for passivo, tanto melhor, pois sua cabeça recebe mansamente e sem crítica os conteúdos tal como fosse uma conta bancária. O educador deposita os conteúdos na cabeça do aluno e no dia da prova avaliará quando de saldo tem na cabeça dos alunos e confere notas.

Educação adestradora que não incentiva a criação ou a busca da informação relevante para o próprio aluno.

Na concepção "bancária" que estamos criticando, para a qual a educação é o ato de depositar, de transferir, de transmitir valores e conhecimentos, não se verifica nem pode verificar-se essa superação. Pelo contrário, refletindo a sociedade opressora, sendo dimensão da "Cultura do silêncio" a "educação bancária" mantém e estimula a contradição.

Daí, então, nela: a) o educador é o que educa; os educandos, os que são educados; b) o educador é o que sabe; os educandos os que não sabem; c) o educador é o que pensa; os educandos, os pensados; d) o educador é o que diz a palavra; os educandos os que escutam docilmente; e) o educador é o que disciplina; os educandos, os disciplinados; f) o educador é o que opta e prescreve sua opção; os educandos, os que seguem a prescrição; g) o educador é o que atua; os educandos, os que têm a ilusão de que atuam, na atuação do educador; h) o educador escolhe o conteúdo programático; os educandos, jamais ouvidos nesta escolha, se acomodam a ele; i) o educador identifica a autoridade o saber com sua autoridade funcional, que opõe antagonicamente à liberdade dos educandos; estes devem adaptar-se às determinações daquele; j) o educador, finalmente, é o sujeito do processo; os educandos, meros objetos (FREIRE, 1981, p.78)

Paulo Freire em contraponto com essa visão autoritária propôs a Pedagogia Problematizadora. Uma prática educacional que de forma alguma trata o educando como mero paciente no processo educacional, mas como um ser ativo na construção do seu próprio conhecimento. Faz-se necessário para o sucesso dessa concepção pedagógica o abandono por 
completo do da oposição professor-aluno. Ela se concretiza pelo diálogo. O educador não é mais visto como aquele educa exclusivamente, mas alguém que também é ensinado pelo aluno. Ambos se educam.

Surge então o educador problematizador que é puro movimento e está sempre colocando em questão seu conhecimento no contato com o saber do aluno que ele também tem em alta conta. São parceiros na construção do conhecimento.

A educação problematizadora, que não é fixismo reacionário, é futuridade revolucionária. Daí que seja profética, e como tal, esperançosa. Dái que corresponda à condição dos homens como seres históricos e à sua historicidade.

Daí que se identifique com eles como seres mais além de si mesmos - como "projetos" -, como seres que caminham para frente, que olham para frente; como seres a quem o imobilismo ameaça de morte; para quem o olhar para trás não deve ser uma forma nostálgica de querer voltar, mas um modo de melhor conhecer o que está sendo, para melhor construir o futuro.

Daí que se identifique como movimento permanente em que se acham inscritos os homens, como seres que se sabem inconclusos; movimento que é histórico e que tem o seu ponto de partida, o seu sujeito, o seu objetivo. (FREIRE, 1981, p.84)

Paulo Freire, em sua obra derradeira publicada um pouco antes de sua morte, faz uma espécie de coroamento de sua obra com o livro Pedagogia da Autonomia.

Nessa obra propõe elencar e comentar os saberes que considerava fundamentais para uma educação libertadora.

Defende logo nos primeiros capítulos que ensinar exige pesquisa e também o papel do professor como alguém que está sempre em formação e que também cria um ambiente educacional de pesquisa de ambos, professor e aluno formando uma comunidade de aprendizagem.

O respeito à bagagem cultural do educando nessa última obra de Paulo Freire permanece como uma espécie de pilar central de sua pedagogia.

Por que não aproveitar a experiência que têm os alunos de viver em áreas da cidade descuidadas pelo poder público para discutir, por exemplo, a poluição dos riachos e dos córregos e os baixos níveis de bem estar das populações, os lixões e os riscos que oferecem a saúde das gentes? Por que não há lixões no coração dos bairros ricos e mesmo puramente remediados dos centros urbanos? (FREIRE, 1996, p. 38)

Defende uma ação pedagógica que vincula os conteúdos ao dia a dia e à concretude da vida dos alunos. E isso é algo que pode ser feito em toda e qualquer disciplina, pois se trata de uma forma de intervenção no mundo. 
Scofano, R. G.

Paulo Freire nunca encarou a educação como algo frio e técnico. Os sentimentos, as emoções e os desejos dos alunos foram extremamente valorizados por ele e em nenhum momento isso representou falta de seriedade.

Estou convencido, porém, de que a rigorosidade, a séria disciplina intelectual, o exercício da curiosidade epistemológica não me fazem necessariamente um ser mal-amado, arrogante, cheio de mim mesmo. Ou em outras palavras não é a minha arrogância intelectual a que fala de minha rigorosidade científica. Nem a arrogância é sinal de competência, nem a competência é causa de arrogância. Não nego a competência, por outro lado, de certos arrogantes, mas lamento neles a ausência de simplicidade que, não diminuindo em nada seu saber, os faria gente melhor. Gente mais gente. (FREIRE, 1996, p.165)

Concluo este artigo cada vez mais convencido de que a Pedagogia de Paulo Freire com sua face aberta ao diálogo tem ainda muito a nos oferecer no sentido de contribuir para a formação de seres humanos éticos, cidadãos conscientes de sua responsabilidade frente à valorização da vida em todas as suas expressões que é algo de que tanto necessitamos no planeta.

A obra freireana está aí o nosso alcance para nos ajudar a construirmos um mundo dialógico e polifônico e também pode funcionar como uma excelente "vacina" contra a violência e o autoritarismo que tanto tem crescido em nosso país

\section{REFERÊNCIAS BIBLIOGRÁFICAS}

ALVES, Rubem. A escola com que sempre sonhei sem imaginar que pudesse existir. Campinas: Papirus, 2001.

FREIRE, Paulo. Educação como prática de liberdade. Rio de Janeiro: Paz e terra, 1977.

FREIRE, Paulo. Pedagogia do oprimido. São Paulo: Paz e Terra, 1981.

FREIRE, Paulo. Pedagogia da Esperança. São Paulo: Paz e Terra, 1992

FREIRE, Paulo. Pedagogia da Autonomia. São Paulo: Paz e Terra, 1996. 